\title{
Imaginación, literatura y política en dos ensayos de Sergio Ramírez
}

\author{
Imagination, Literature and Politics in two essays \\ by Sergio Ramírez
}

\section{Marco Polo Taboada Hernández}

La conquista de un nombre literario es la conquista de un poder. José María de Hostos, La peregrinación

Resumen:

En el panorama literario latinoamericano contemporáneo, la región centroamericana ha gozado de escasa atención crítica, pese al renombre del que gozan algunos autores. Entre los escritores consolidados internacionalmente, destaca el nicaragüense Sergio Ramírez, quien ha publicado una vasta obra que abarca la novela, el cuento, el testimonio y el ensayo. En este artículo analizo dos ensayos, Mentiras verdaderas y El viejo arte de mentir, en los que Ramírez reflexiona en torno a los atributos y las posibilidades discursivas de la ficción narrativa. A partir de estos textos, hasta ahora poco explorados por los especialistas, examino, primero, las implicaciones de la diferencia (política e ideológica) que el autor plantea entre imaginación y fantasía; después, el matiz que distingue la propuesta de Ramírez sobre la ficción de la planteada años antes por Mario Vargas Llosa; por último, la forma en que el nicaragüense valida la narrativa ficcional como un discurso irrefutable y superior a cualquier otro.

\footnotetext{
* Universidad Nacional Autónoma de México.
} 
Palabras clave:

Sergio Ramírez, ficción y política, ensayo centroamericano, literatura nicaragüense, Mentiras verdaderas.

\section{Abstract:}

In the contemporary Latin American literary scene, the Central American region has received little critical attention, despite the popularity of some of its authors. Among these internationally consolidated writers, the Nicaraguan Sergio Ramírez stands out, having published a vast body of work that includes novels, shortstories, testimonies and essays. In this paper, I analyze two of Ramírez's essays, Mentiras verdaderas and El viejo arte de mentir, in which the author reflects on the attributes and discursive possibilities of fiction. In these texts, little explored by specialists so far, First, I examine the implications of the difference (political and ideological), raised by Ramírez, between imagination and fantasy. Then, the nuance that distinguishes Ramirez's proposition of fiction from the one proposed years before by Mario Vargas Llosa; finally, the way in which the Nicaraguan validates the fiction narrative as an irrefutable discourse superior to any other.

Keywords:

Sergio Ramírez, Fiction and Politics, Central American essay, Nicaraguan literature, Mentiras verdaderas.

Sergio Ramírez Mercado (Masatepe, 1942), calificado por Ángel Rama como "escritor contestatario" (45) y ampliamente conocido por formar parte del grupo revolucionario que derrocó a la dinastía Somoza en Nicaragua en 1979 — y, más tarde, por fungir como vicepresidente de su país-, ha logrado conciliar los dos oficios ejercidos con igual esmero a lo largo de su vida: la literatura y la política. Tal y como afirma el mismo Rama:

Su obra narrativa nunca ha estado escindida de su plena integración en el movimiento popular de su país, de una lucha antiimperialista diseñada por el propio Sandino, de su reclamo por una justicia social, pero también de la impostergable 
necesidad de modernizar las sociedades latinoamericanas. Su literatura responde a ambas aspiraciones. (271)

Escritor político y político escritor, autor de una vasta obra - la cual abarca la novela, el cuento, el testimonio y el ensayo-, Ramírez ha sido galardonado con el Premio Dashiell Hammett en 1990 por Castigo divino, con el Premio Alfaguara de novela en 1998 por Margarita, está linda la mar y con el Premio Cervantes en 2017. Pese a tales distinciones, su fecunda y versátil producción literaria no se corresponde con las hasta ahora exiguas aproximaciones críticas generadas desde el ámbito académico. Por si fuera poco, los textos que integran el corpus ensayístico del nicaragüense conforman, sin duda, el sector más desatendido; razón por la cual estimo oportuno esbozar aquí una aproximación a Mentiras verdaderas (2001) y El viejo arte de mentir (2004), en vista de que ambos libros se organizan en torno a los aspectos que, de acuerdo con el autor, son fundamentales en la creación de narrativa de ficción, al tiempo que develan la tirantez entre el ámbito político y el literario.

Si, como asevera John Skirius en el prólogo a su compilación de ensayos hispanoamericanos del siglo XX, "los novelistas y poetas con frecuencia usan el ensayo en sus diversas formas para expresar un mensaje perentorio con mayor impacto inmediato de lo que pudiera tener una obra de ficción o de poesía" (29-30), resulta necesario inquirir sobre las características y los alcances de tal mensaje "perentorio" en los textos de Ramírez. Aventuro desde ahora que, a la vez que Mentiras verdaderas y El viejo arte de mentir le permiten al nicaragüense plantear sus inquietudes en torno a las posibilidades de la ficción literaria, expresan también — de manera sutil pero no por ello menos importante- su deseo (no desprovisto de contradicciones) de brindarle al ámbito literario la supremacía sobre cualquier otro tipo de discursividad, para legitimar así su propio lugar de enunciación y sus intervenciones sobre política. ${ }^{1}$ No debe

${ }^{1}$ El estrecho vínculo entre literatura, historia y política había sido ya tratado por el autor en su temprano (y pionero) ensayo "Balcanes y volcanes (la pluma 
extrañar, por tanto, que para la consecución de tales propósitos, en ambos ensayos cobren vital importancia las relaciones que la mentira literaria establece con la Historia, la política y la peculiar realidad latinoamericana.

\section{La literatura: el arte de saber mentir}

La semejanza entre Mentiras verdaderas y El viejo arte de mentir es palmaria: en uno y otro tex to sobresalen tres aspectos fundamentales: el lenguaje, la verosimilitud y la imaginación. La literatura - ese viejo arte de mentir, a decir de Ramírez- se construye con base en esta indisociable trinidad.

El lenguaje es la materia prima del escritor, quien por medio de la palabra crea "una realidad paralela. . . una realidad nueva,

debajo del sombrero)" de 1973. En este texto, Ramírez enlaza la inserción de Centroamérica en la economía mundial —a partir de la exportación de cafécon la consolidación de las dos corrientes fundamentales de la literatura de la región: el costumbrismo y el modernismo. A decir del autor, una y otra vertientes: “tomarán cauces de sentido contrario y tendrán sin embargo ambas, mucho que ver con las formas artísticas recién arribadas [del viejo continente] y con los ideales de la cultura europea. La inmovilidad posterior, no sólo de la sociedad centroamericana en su conjunto, sino principalmente de las élites que sufrirán el empobrecimiento crónico de sus apropiaciones iniciales, harán que ambas corrientes se instalen como gusto público y como arte oficial."

Si bien algunos de los asertos del autor son poco más que cuestionables (como aquel que sostiene que "la literatura centroamericana nace como literatura contemporánea”, con lo cual desestima las manifestaciones culturales prehispánicas y coloniales), su estudio tiene la virtud, primero, de subrayar la relación entre los textos literarios y los distintos referentes sociales/culturales a los que acuden, ya sean los europeos o los locales; después, de indagar sobre la relación entre la literatura y el mercado, y la búsqueda de cauces expresivos que otorguen rasgos distintivos a la literatura del Istmo. Según Ramírez, de un lado, lo vernáculo/costumbrista tendrá su expresión narrativa más lograda en Salvador Salazar Arrué; mientras que, del otro, el modernismo alcanzará su punto más álgido con Rubén Darío. Ambas figuras serán, a la postre, la base sobre la que se asienta la tradición literaria, de la cual el propio nicaragüense abreva y en la cual se inserta. 
que en ningún caso será igual a lo que nosotros, como punto de partida, estamos identificando como realidad" (Ramírez, El viejo arte 45). La realidad — a secas - no es otra cosa que el mundo factual, objetivo, que el literato transforma a través del lenguaje. Este proceso es, afirma Ramírez, similar al que utiliza el carpintero cuando convierte un árbol en mueble, pues "entre el árbol y el mueble, entre la materia del árbol y la transformación de la materia en un mueble, queda de por medio la apropiación de esa materia, apropiación que [en el caso del autor de ficciones] es el proceso de convertir la realidad en imaginación y la imaginación en lenguaje" (Mentiras 90). El símil empleado me parece muy significativo, pues la transformación del árbol en mueble — es decir, del lenguaje en artificio textual - implica la conversión de algo "natural" no solo en un objeto "artificial", sino y sobre todo, en un instrumento que cumple una función específica, desprovista de gratuidad alguna. Para decirlo en grueso, así como un mueble tiene una finalidad práctica y particular, lo mismo ocurre con la ficción narrativa: tiene un uso social (cuyos rasgos Ramírez irá definiendo en lo sucesivo) y excede la ornamentación que, de acuerdo con cierta perspectiva estetizante, suele atribuírsele al arte.

Ahora bien, ¿cómo opera, entonces, dicho trocamiento de la realidad en imaginación? En vista de que la realidad "es fruto de la percepción particular de cada uno, por mucho que se base en elementos concretos" (El viejo arte 20), las apreciaciones sobre un mismo objeto habrán de ser distintas de acuerdo con los "prejuicios, experiencias, formación cultural, miedos, esperanzas" (21) de cada individuo. La subjetividad es, en suma, el factor que según el nicaragüense potencia el distanciamiento entre lo real y lo aprehendido y revela la "falsedad de la verdad" (21). En esta paradoja se cifra la condición mentirosa de la literatura: puesto que la verdad es una "deidad escurridiza y, las más de las veces, inaprensible" (22), el escritor postula su visión particular del mundo objetivo y lo convierte en imaginación, es decir, en mentira. Sin embargo, las mentiras del literato obedecen a reglas precisas y, entre ellas, la verosimilitud cumple un papel primordial. 
No basta con mentir, hay que persuadir; hacer que lo escrito parezca real. Esta es una de las premisas básicas de Ramírez: el autor de ficciones debe ofrecerle al lector "mentiras verdaderas" (Mentiras 20). ¿Qué significa este oxímoron? Que "las mentiras verdaderas tienen que ser creíbles" (20). La verosimilitud es el rasero con el cual se mide la credibilidad del relato o, dicho en palabras del autor, la "regla sagrada" (El viejo arte 19) del escritor. Y subraya: "los datos que ofrezcamos para revestir la historia tienen que ser veraces bajo todo punto, de modo que el lector, al compararlos con su propia experiencia, concluya que son reales. Es lo que en literatura llamaremos realismo, que es cuando la imaginación surge como una emanación o transformación del material de la realidad" (20; cursivas mías). Queda claro que, para el autor de Margarita, está linda la mar, la imaginación del creador de ficciones debe estar supeditada a la verosimilitud. ${ }^{2}$ Pero, ¿qué implicaciones tiene para Ramírez la definición de realismo? Si nos ceñimos a lo expresado en la cita anterior, el realismo resulta del contrato de lectura establecido entre autor y lector: el primero redacta un texto a su parecer verosímil; el segundo lo percibe como tal. Ramírez remarca que:

el lector precisa de credibilidad y nosotros, como escritores, tenemos que dársela en la narración sin ninguna clase de trampas. Si fallamos en esa primera oferta de credibilidad, que depende de la verosimilitud (el símil de lo verdadero), estaremos derrumbando desde el primer momento el edificio donde ambos tenemos que vivir, escritor y lector. (El viejo arte 22)

\footnotetext{
${ }^{2}$ Vale aquí recordar que, según Helena Beristáin, la verosimilitud es la “ilusión de coherencia real o de verdad lógica producida por una obra que puede ser, inclusive, fantástica. Dicha ilusión proviene de la conformidad de su estructura con las convenciones características de un género en una época, sin necesidad de guardar correspondencia con situaciones y datos de la realidad extralingüística" (s. v. "verosimilitud"). En el fragmento siguiente me ocuparé del distingo que Ramírez establece entre "imaginación” y "fantasía".
} 
Esta relación de "complicidad entre escritor y lector, engañador y engañado, seductor y seducido" (Mentiras 15) no está desprovista de inconvenientes teóricos, pues, como afirma Roman Jakobson:

Declaramos realistas a las obras que nos parecen verosímiles, fieles a la realidad. Desde ya la ambigüedad es evidente:

1.- Se trata de una aspiración, de una tendencia, es decir que se llama realista la obra propuesta como verosímil por el autor. (Significación A).

2.- Se llama realista a la obra que es percibida como verosímil por quien la juzga. (Significación B). (71-72) ${ }^{3}$

No queda claro si Ramírez alude a la significación A o B, o quizá (parece lo más probable) no tiene en cuenta esta distinción. En primer término, sus planteamientos sugieren que es el escritor quien asume el deber de realizar un texto verosímil (caso A) y que, como consecuencia de este propósito, el lector habrá de reconocer su tono "realista" (caso B). Empero, es dable de igual manera, filiar la definición de realismo a la que el nicaragüense se refiere - es decir, la "transformación de la realidad en imaginación"- con la que Jakobson caracteriza a la corriente artística del siglo XIX del mismo nombre (significación C). La gran cantidad de referencias literarias de este periodo incluidas en ambos ensayos (Dickens, Tolstói, Balzac, entre otros), resaltan el vínculo entre el realismo decimonónico y el arte de contar mentiras verdaderas. Sea de ello lo que fuere, lo cierto es que para Ramírez existen dos formas distintas

${ }^{3}$ De la significación A se desprenden dos posibilidades: A1: "la tendencia a deformar los cánones artísticos vigentes, interpretada como un acercamiento a la realidad" y A2: "la tendencia conservadora limitada al interior de una tradición artística e interpretada como fidelidad a la realidad”. La significación B, por su parte, también posee dos variantes: B1: "Yo [lector] soy revolucionario en relación a los hábitos artísticos vigentes y percibo su deformación como un acercamiento a la realidad" y B2: "Yo soy conservador y percibo la deformación de los hábitos artísticos vigentes como una alteración de la realidad" (74). 
e irreconciliables de ficcionalizar la realidad a través de la literatura: a partir de mentiras verdaderas o de mentiras falsas.

\section{Imaginación y fantasía}

En su reflexión sobre la escritura de ficción, Sergio Ramírez diferencia las mentiras verdaderas de las mentiras falsas. Las primeras, verosímiles y "realistas", son hijas de la imaginación; las otras, desproporcionadas e incongruentes, derivan de la fantasía. "Aun en los libros donde la imaginación no conoce límites, como en Las mil y una noches, no se cuentan falsedades, no se cuentan fantasías. La imaginación es seria, la fantasía no" (Mentiras 20-21; cursivas mías). ¿En qué consiste la seriedad de lo imaginativo frente a lo fantasioso? En su carácter realista, ya sea en el sentido A, B o C que Jakobson le atribuye, pues el autor utiliza con deliberada ambigüedad el término para reforzar sus hipótesis. Así, "la realidad no es más que la imaginación en su estado sólido; la imaginación es una propiedad diferente del mismo cuerpo, es decir, la realidad en su estado gaseoso. . . La fantasía no es un cuerpo, ni siquiera un cuerpo gaseoso" (21). Para el autor de Castigo divino, el realismo, como forma de expresión literaria, es la vía no solo idónea, sino aparentemente natural de escritura que se desprende de la realidad extratextual ${ }^{4} \mathrm{o}$, dicho de otro modo, es el mecanismo óptimo para representar y, ante todo:

proyectar el mundo en términos que nunca dejen de tener congruencia. Balzac quería la reproducción del mundo real en el mundo de la ficción. La novela como espejo seductor e implacable de la realidad. El velo de la imaginación en el

${ }^{4}$ Otras formas contemporáneas del realismo, como el denominado realismo mágico (o, para decirlo en términos de Irlemar Chiampi, "realismo maravilloso"), se ciñen, a decir de Ramírez, a la narración imaginativa y no a la fantasiosa. Cfr. Chiampi, Irlemar. El realismo maravilloso. Forma e ideología en la novela hispanoamericana. 
rostro de la verdad, tan sutil y evanescente como su propia emanación, su propia alma, no su máscara. (Mentiras 76)

Ya sea como estado gaseoso de la realidad sólida o como reflejo de esta, la imaginación debe siempre apelar a la credibilidad. Para discernir con mayor claridad el valor de la imaginación en oposición a la fantasía, vale la pena examinar el material con el que Ramírez ejemplifica cada una de estas vertientes.

La literatura de imaginación (es decir, la que cuenta mentiras verdaderas) es, como ya se dijo antes, siempre verosímil o realista (en cualquiera de las tres definiciones de Jakobson). Autores y subgéneros narrativos de diversa índole así como de distintas épocas desfilan en el recuento de lo imaginativo, mostrando la permanente tensión entre el mundo empírico y el mundo deseado: Miguel de Cervantes, Franz Kafka, Ray Bradbury, Somerset Maugham, Gustave Flaubert, Rómulo Gallegos, José Eustasio Rivera, Carlos Fuentes, Gabriel García Márquez, entre otros. ${ }^{5}$ Los ejemplos de creaciones fantasiosas (las que originan mentiras falsas) son, en cambio, pocos, pero no por ello menos esclarecedores: por un lado, los libros de caballería, que "siempre proponen situaciones inverosímiles, y se doblegan bajo el peso de sus propias mentiras, un alud de trapo, madera y cartón" (25); $;$ por el otro, "los animales de la zoología fantástica de Walt Disney —incluyendo los elefantes alados - que no conocen el mal sino como una contradicción plana

\footnotetext{
${ }^{5}$ Merece la pena precisar que, de acuerdo con los planteamientos del prosista nicaragüense, lo que él descalifica como "fantasía" no guarda relación alguna con la noción de literatura fantástica a la que Tzvetan Todorov y tantos otros estudiosos han dedicado extensos trabajos. Las líneas siguientes dejan ver qué es lo que para Ramírez implica narrar "mentiras falsas", en oposición a las "mentiras verdaderas" que enaltece en sus ensayos.

${ }^{6}$ No deja de llamar la atención esta lectura descontextualizada de Ramírez sobre las novelas de caballería. El nicaragüense desatiende que, en su momento, lo expresado en los libros de caballería era considerado real, en vista de que no existía (como hoy en día) la distinción entre ficción literaria y realidad extratextual; por el contrario, lo escrito poseía una autoridad irrefutable y era asumido como cierto.
} 
y absoluta del bien tan simple y sin relieves que representan en sus colores planos" (88).

Si la verosimilitud — la propuesta por el autor, la percibida por el lector o la de la corriente literaria del siglo XIX- es el punto de engarce, a la vez que la evidencia de carácter artístico, entre textos tan disímiles como Las mily una noches, El ingenioso bidalgo don Quijote de la Mancha y Cien años de soledad, la exageración (y su concomitante falta de credibilidad) es, por el contrario, el factor común de los productos de la fantasía. Pero hay más: lo que Ramírez denuncia de los libros de caballería no son solo sus incongruencias y desproporciones, sino otras "fallas", a su parecer, imperdonables: 1) la forma en que este género narrativo, al reproducir su estructura ad nauseam, se convirtió en "un cliché, un molde consabido en el que vaciar la trama, que para el lector entrenado no depara ya sorpresas" (27); y 2) que "su paisaje, el campo de su acción, sus antihéroes, son arcaicos. Y ellos [los protagonistas], como reflejo de su entorno fatal, respiran el aire de la decrepitud y se vuelven también arcaicos" (28-29). En otras palabras, el defecto del Amadís y compañía reside en su producción en serie (esa creación con base en "moldes") y en la estandarización de sus personajes (estereotipados, no creíbles y, por tanto, perecederos). Algo similar ocurre con los personajes de Disney: su maniqueísmo y simpleza (esa "falta de relieves") los separan, inexorablemente, de la verdadera imaginación.

La falta de fidelidad a la realidad que Ramírez imputa a estas creaciones fantasiosas (llaneza y esquematismo, en resumen) no se reduce a sus deficiencias compositivas o estéticas sino, sobre todo,

7 De nuevo, el autor de Margarita, está linda la mar obvia que tales "sorpresas", es decir, la originalidad, no era un valor vigente. Baste recordar que acudir a la "fórmula", reproducir el modelo canónico (la afamada imitatio) era el principal atributo de un texto. En defensa de Ramírez, bien puede decirse que su ofensiva tiene como objetivo no los libros de caballería en sí mismos, sino la reivindicación de estos que hiciera Mario Vargas Llosa en su ensayo Carta de batalla por Tirant lo Blanc (1991). Este detalle no es irrelevante si se tiene en cuenta que la noción de "mentira" que encomia es, como se verá, política e ideológicamente distinta de la que Vargas Llosa defiende en La verdad de las mentiras. 
a las ideológicas. El denuesto del nicaragüense hacia los dibujos animados y los libros de caballería se funda, aunque el autor no lo explicita nunca, en el carácter "popular" y "masivo" de ambos discursos. Bajo esta luz, las novelas de caballería:

fueron best-sellers en su tiempo, un género preferido porque relataba las mentiras de moda, las que el público demandaba oír; lecturas verdaderamente populares que encantaban y entretenían a miles de ociosos: sólo del Amadís de Gaula se imprimieron entre 1508 y 1589 más de treinta ediciones, y no hay duda de que despertaban la imaginación antes de que llegaran a degradarse en pura fantasía. (27; cursivas mías)

La falsedad de historias como la de Esplandián o Galaor consiste —además de su exageración y reiteración formal, como ya se dijoen su desmedida complacencia para con el público: eran mentiras "de moda" que satisfacían las expectativas de los "ociosos" escuchas. Para Ramírez, los libros de caballería son el germen de la literatura sometida a las leyes del mercado, estereotipada, vacía de sentido y completamente autónoma en tanto desvinculada de lo social. ${ }^{8}$

En su diatriba contra los emblemáticos personajes de Walt Disney, el ensayista les reprocha ese mismo distanciamiento de la complejidad del entramado social. Y más aun: en su crítica subyace una franca

${ }^{8}$ En definitiva, los libros de caballería no estaban apartados del contexto social en que se producían y difundían: representaban una forma bastante extendida y predominante de concebir la realidad extratextual. Si Ramírez los denuesta es porque su concepto de imaginación está estrechamente ligado a un ejercicio crítico de las condiciones económicas, políticas y sociales imperantes. Nótese la coincidencia entre estas ideas de Ramírez y las que, varias décadas antes, propuso al respecto José Carlos Mariátegui: "la ficción no es libre. Más que descubrirnos lo maravilloso, parece destinada a revelarnos lo real. La fantasía, cuando no nos acerca a la realidad, nos sirve bien poco. Los filósofos se valen de conceptos falsos para arribar a la verdad. Los literatos usan la ficción con el mismo objeto. La fantasía no tiene valor sino cuando crea algo real. Esta es su limitación. Este es su drama” (390). 
oposición a los valores que transmiten dichos dibujos animados. La fantasía es nociva porque defiende la ideología dominante y caricaturiza las relaciones entre los individuos. ${ }^{10}$

Las mentiras falsas fomentan la alienación: desvinculan al individuo de su contexto inmediato, lo apartan de la Historia, lo reducen a la contemplación irreflexiva. La fantasía posee, para Ramírez, los mismos inconvenientes que Horkheimer y Adorno hallan en los productos generados por la industria cultural, pues en una y otra:

El espectador no debe necesitar de ningún pensamiento propio: el producto prescribe toda reacción, no en virtud de su contexto objetivo (que se desmorona en cuanto implica al pensamiento), sino a través de señales. Toda conexión lógica que requiera esfuerzo intelectual es cuidadosamente evitada. Los desarrollos deben surgir, en la medida de lo posible, de la situación inmediatamente anterior, y no de la idea del todo. (Horkheimer y Adorno 181-2)

Mientras que la fantasía evita el pensamiento propio, la imaginación lo procura. La primera opera a través de señales inconexas, la segunda, en contraparte, pretende ofrecer una idea del todo; aquella empaña la realidad, esta la proyecta. ${ }^{11}$ La imaginación, se deduce

${ }^{9}$ No hay duda de que Ramírez suscribiría la siguiente afirmación: "Si los dibujos animados tienen otro efecto, además del de acostumbrar los sentidos al nuevo ritmo del trabajo y de la vida, es el de martillear en todos los cerebros la vieja sabiduría de que el continuo maltrato, el quebrantamiento de toda resistencia individual, es la condición de vida en esta sociedad. El Pato Donald, en los dibujos animados, como los desdichados en la realidad, reciben sus golpes para que los espectadores aprendan a habituarse a los suyos" (Horkheimer y Adorno 183).

${ }^{10}$ Es posible relacionar el desprecio del autor de Mentiras verdaderas por las criaturas de Walt Disney con el análisis que sobre estas realizaron Ariel Dorfman y Armand Mattelart. Según afirma Héctor Schmucler en el prólogo a este libro, "Donald es la metáfora del pensamiento burgués que penetra insensiblemente en los niños a través de todos los canales de formación de su estructura mental” (6).

${ }^{11}$ La distinción entre fantasía e imaginación que hace Ramírez es similar a 
de lo anterior, constituye la piedra angular del arte de saber mentir, un proceso que va "del mundo exterior hacia el mundo interior, y viceversa" (El viejo arte 71). ¿Cómo se representa este proceso en la escritura? ¿Qué elementos de la realidad recoge y aprehende la literatura de imaginación, es decir, la erigida con base en mentiras verdaderas? Considero que la posición asumida por Sergio Ramírez sobre las cualidades y posibilidades de la ficción en relación con la Historia y con la política, puede apreciarse con mayor claridad si se la compara con la de Mario Vargas Llosa, pues la exposición del nicaragüense vuelve sobre las ideas plasmadas por el peruano en $L a$ verdad de las mentiras (1990) y se distancia de ellas.

\section{Vargas y Ramírez: dos formas de encarar la ficción}

No son escasos los puntos en común entre las hipótesis defendidas por Ramírez en sus dos ensayos y los argumentos que, años atrás, esbozara Vargas Llosa en La verdad de las mentiras. Para ambos autores la mentira es condición sine qua non de la literatura: al convertirse en lenguaje, los hechos narrados cobran un cariz distinto. "Las mentiras de las novelas . . llenan las insuficiencias de la vida" (Vargas 12). $\mathrm{Al}$ modificar la realidad, la literatura le agrega algo: permite entrever la insatisfacción humana que anida en toda ficción. " "En efecto,

la que utiliza Umberto Eco para diferenciar la novela "popular" de la novela "problemática". Según el italiano, en la novela popular: "se librará siempre una lucha del bien contra el mal, que, cueste lo que cueste, siempre se resolverá —independientemente de que el desenlace rebose felicidad o dolor- a favor del bien, definido según los términos de la moralidad, de los valores y de la ideología al uso. La novela «problemática» propone, en cambio, unos finales ambiguos precisamente porque tanto la felicidad de Rastignac como la desesperación de Emma Bovary ponen puntual y ferozmente en cuestión el concepto adquirido de «Bien» (y de «Mal»)" (17).

12 Este planteamiento de Vargas Llosa-por lo demás, bastante popular entre los escritores-guarda relación con las hipótesis formuladas por Sigmund Freud respecto a la insatisfacción como aliciente de la creación artística y, particularmente, literaria: "Es lícito decir que el satisfecho nunca fantasea; sólo 
todas las novelas mienten — no pueden hacer otra cosa- pero ésta es sólo una parte de la historia. La otra es que, mintiendo, expresan una curiosa verdad, que sólo puede expresarse disimulada y encubierta, disfrazada de lo que no es" (Vargas 6; cursivas mías). La "verdad de las mentiras" se traduce como la facultad de la literatura para evidenciar, por medio de la imaginación, rasgos de la condición humana que, por su fidelidad a los acontecimientos, el libro de historia y el texto periodístico no pueden transmitir.

La ficción narrativa es, para uno y otro escritor, un discurso privilegiado. A decir de Vargas, "sólo la literatura dispone de las técnicas y poderes para destilar ese delicado elixir de la vida: la verdad escondida en el corazón de las mentiras humanas" (Vargas 15). ${ }^{13}$ Según Ramírez, "es la maestra de la dialéctica totalizante, la que escribe, describe, dice, quiere decir, explicarlo todo" (Mentiras 122). Como puede apreciarse, ambos autores tienen en muy alta estima su oficio y no dudan en conferirle a este una función específica en el entramado social: descubrir, a "contraluz", verdades. Pero, ¿qué tipo de verdades? ¿Son estas, acaso, las mismas para cada uno de los novelistas aquí citados?

Mario Vargas Llosa sostiene que la ficción narrativa proyecta las inconformidades del ser humano pero, sobre todo, las individuales. La literatura cuenta, a su parecer, "la historia privada de las naciones" (20; cursivas mías). El acontecer público es el objeto de estudio del discurso histórico, de pretensiones científicas; las historias privadas, en cambio, son el material referencial del que se nutre la literatura. Una y otra disciplina — historia y literatura— mantienen una relación de complementariedad: la narración histórica "es indispensable e insustituible para saber lo que fuimos y acaso lo que seremos como

lo hace el insatisfecho. Deseos insatisfechos son las fuerzas pulsionales de las fantasías, y cada fantasía singular es un cumplimiento de deseo, una rectificación de la insatisfactoria realidad" (123).

${ }^{13}$ Sin embargo, no toda literatura tiene la capacidad de manifestar esa "verdad oculta". El nicaragüense concuerda con Vargas en su distingo entre la "buena" y "mala" literatura: la "buena" es persuasiva y verosímil; la "mala" no ilusiona y es, en consecuencia, in-creíble, falaz. 
colectividades humanas" (20); las historias individuales relatan "lo que somos como individuos y lo que quisimos ser y no pudimos serlo de verdad y debimos por tanto serlo fantaseando e inventando [y eso] sólo la literatura lo sabe contar" (21).

Preservar intacta la frontera entre historia y literatura es, para Vargas Llosa, una prerrogativa de las sociedades que denomina "abiertas", en vista de que en ellas "la ficción y la historia coexisten, sin invadir ni usurpar la una los dominios y las funciones de la otra" (16). En las sociedades "cerradas", se deduce de lo anterior, ocurre lo contrario: "la ficción y la historia han dejado de ser cosas distintas y pasado a confundirse constantemente de identidades como en un baile de máscaras" (16). La autonomización de la literatura — su separación de otras disciplinas (la historia, el periodismo) - es el principal atributo de las sociedades que el autor arequipeño denomina "abiertas" o democráticas. En tales sistemas, asevera, la literatura, restringida al orden de lo personal e íntimo, es un salvoconducto, una manera de "afirmar la soberanía individual . . . de preservar un espacio propio de libertad, una ciudadela fuera del control del poder y de las interferencias de los otros" (20). La ficción adquiere, de acuerdo con esta hipótesis, una función "liberadora": le permite al sujeto (autor y lector, en este caso) fantasear, jugar a ser otro y, a la vez, aislarse de los demás. En esta brecha que se abre entre el individuo y la sociedad (al igual que la que divide a la literatura de la historia) el autor de La casa verde halla la libertad originaria de la cual habrán de surgir, derivadas, todas las demás. ${ }^{14}$

${ }^{14}$ Es, a mi parecer, significativo que La verdad de las mentiras apareciera pocos meses antes de que Vargas Llosa anunciara su candidatura a la presidencia del Perú. Las ideas expresadas en este libro, vistas a "contraluz" (tal como el autor sugiere que leamos las mentiras de la literatura), revelan la forma en que él legitima, desde su condición de escritor, su incursión en la política. Si la ficción evidencia las insatisfacciones que bullen en el alma humana, ¿no es el escritor el más indicado para reconocerlas y, acaso, paliarlas? Además, la incisiva distinción de Vargas entre las sociedades "abiertas" y las "cerradas", acentúa su filiación político/ideológica: las sociedades "cerradas" (o "autoritarias", entre las que reconoce a la Unión Soviética y a sus antepasados y "compatriotas" los Incas) 
Sergio Ramírez encara de forma distinta la relación entre historia y literatura. Para él la ficción tiene, desde su gestación, un carácter social. En América Latina, declara, no es posible

reservar para la novela un sector de intimidad, que quiere decir relato de las vidas privadas, sin que la Historia pública no aparezca con sus colores dominantes, no sólo como telón de fondo sino como un escenario vivo que se interrelaciona con los escenarios privados. Y no estamos hablando de una categoría de «novela histórica», sino de la novela en general, como relato intervenido por la Historia pública. (El viejo arte 68-69) ${ }^{15}$

Toda novela es histórica en la medida en que debe dar cuenta de las contradicciones sociales. No basta — parece ser la consigna de Ramírez- con circunscribir la narrativa al ámbito de lo privado, a la esfera de la intimidad, tal como propone Vargas; es imprescindible referir las vicisitudes de la vida pública. En vista de lo anterior, no resulta extraño que el nicaragüense asevere:

Casi no hay acontecimiento privado per se. Es escasa la posibilidad de contar una historia de amor dentro de las paredes de una alcoba sin que los amantes tengan que verse sobresal-

mutilan la imaginación y, con ella, el germen de todo "auténtico" progreso. El progreso auténtico, se deduce de su argumentación, es privativo de las sociedades "abiertas" y se sintetiza en el derecho que los individuos poseen para imaginar, pese a que "el precio de la libertad de que gozan se paga a menudo en tremendas desigualdades de fortuna $-\mathrm{y}$ lo que es peor- de oportunidad entre sus miembros" (18). Las desigualdades económicas y sociales se resarcen, según Vargas, con la libertad de pensamiento que poseen los individuos. Ramírez, gran admirador del autor de La ciudad y los perros en el plano artístico, disiente de él en política. A propósito del fracaso electoral del peruano, confiesa: "algo de culpa en esa derrota habrá que atribuir a su propio proyecto neoliberal, inspirado, como él mismo lo confiesa ... en las ideas fundamentalistas y casi teologales de Margaret Thatcher" (Oficios compartidos 143).

${ }^{15}$ Ramírez escribe "Historia" así, con mayúsculas, para recalcar la importancia de los sucesos sociales ante las historias "minúsculas" o particulares. 
tados por los ruidos de la calle o el rumor de una multitud inconforme, unos disparos de fusil, el sordo estallido de los cañones. (El viejo arte 115)

Los relatos de historias individuales no son posibles sin su correlato - ese "escenario vivo" - colectivo. La posibilidad de eludir ese llamado del exterior en la literatura resulta, para Ramírez, no solo escasa sino también estéticamente inviable. ${ }^{16}$

Si se atienden las observaciones de Liliana Weinberg respecto a las estrategias argumentativas y expositivas del género ensayístico, no puede obviarse que este proyecta a "sus 'amigos', sus 'aliados', sus 'contrincantes' y sus 'enemigos', sus afinidades y rechazos. De allí que el ensayo sea a la vez táctica y estrategia de un combate simbólico, para el cual puedan ponerse imágenes como la de una "batalla de ideas" (55). Así, entre los "contrincantes" de Sergio Ramírez habría que ubicar a Mario Vargas Llosa, no como un oponente personal ni mucho menos, sino como partidario de una perspectiva sobre la función de la narrativa de ficción (más autónoma e individual, a decir del peruano) que se opone a la que el propio Ramírez defiende.

En aras de afianzar su noción de la literatura entretejida con el devenir social, tan opuesta a la de su colega peruano, el nicaragüense da un paso más: generaliza sus aseveraciones a un corpus al mismo tiempo más vasto y específico, la novelística latinoamericana. En

${ }^{16}$ Ese distanciamiento de lo social es justo lo que Ramírez condena de los libros de caballería: la "autonomía perfecta" de estos, su falta de apego a la realidad extratextual se convirtió en "su ruina; [porque] desprendió de la vida su fabulación y quedaron vagando en el espacio oscuro como pedazos de un mundo muerto y desaparecido" (Mentiras 30; cursivas mías). La insistencia del nicaragüense en la ligazón entre la serie social y la serie literaria es patente en las líneas iniciales del discurso que pronunció cuando le fue otorgado el Premio Cervantes, donde manifiesta su oposición frente al gobierno de su otrora compañero Daniel Ortega: "Permítanme dedicar este premio a la memoria de los nicaragüenses que en los últimos días han sido asesinados en las calles por reclamar justicia y democracia, y a los miles de jóvenes que siguen luchando, sin más armas que sus ideales, porque Nicaragua vuelva a ser República” ("Discurso íntegro”). 
este orden de ideas, la novelística del subcontinente se caracteriza, según él, por imbricar las historias privadas con la Historia pública para resaltar, siempre, los efectos de esta última sobre aquellas: "Para nuestros escritores, la Historia pública y la ambición de contarla, domina el discurso narrativo y se sitúa por encima de las historias con minúsculas, que son las historias privadas" (El viejo arte 68; cursivas mías). Y más: los acontecimientos sociales, singulares y extraordinarios por sí mismos, obligan al novelista a referirlos en sus textos, pues no hay posibilidad de escapar a su influjo: "nuestra Historia pública, que nunca ha sido una historia común, seguirá corriendo por delante de los novelistas para desafiarlos y para forzarlos a entrar en su cauce de manera ineludible" ${ }^{17}$ (El viejo arte 106; cursivas mías).

La narrativa persigue a la Historia, intenta aprehenderla, explicarla, darle sentido. Según Ramírez, "éste es un punto de verdadera importancia. En América Latina, el novelista sigue estando en capacidad de sustituir al historiador, no sólo en cuanto a los hechos del pasado remoto, sino en cuanto al acontecer diario que se acumula frente a nuestros ojos asombrados" (El viejo arte 123; cursivas mías). El linde entre literatura e historia (tan defendido por Vargas Llosa) es, para el autor de ¿ Te dio miedo la sangre?, lábil. Si el novelista está en condiciones de relevar al historiador es porque sus ficciones — forjadas con mentiras verdaderas - exhiben las omisiones de la historiografía. La literatura asume un cometido explícito: llena los intersticios que dejan otros discursos ${ }^{18} \mathrm{y}$, en consecuencia, se sitúa sobre ellos.

${ }^{17}$ Ramírez hace eco de las ideas implantadas por Alejo Carpentier sobre la peculiaridad de la historia en América Latina: "por la dramática singularidad de los acontecimientos, por la fantástica apostura de los personajes que se encontraron, en determinado momento, en la encrucijada mágica de la Ciudad del Cabo, todo resulta maravilloso en una historia imposible de situar en Europa y que es tan real, sin embargo, como cualquier suceso ejemplar de los consignados, para pedagógica edificación, en los manuales escolares". El texto del cubano culmina con la siguiente aseveración: “¿Pero qué es la historia de América toda sino una crónica de lo real-maravilloso?” (Carpentier 17-18).

${ }^{18}$ Ramírez, de acuerdo con las aseveraciones de Melba Julia Rivera, “insistirá en que, frente a esta sociedad [latinoamericana] . . recobra importancia la 
No es irrelevante, para el caso, que entre las fuentes literarias en las que se apoya Ramírez para ejemplificar el entrecruzamiento entre la Historia y la ficción narrativa esté, precisamente, la Historia verdadera de la conquista de la Nueva España de Bernal Díaz del Castillo. ¿Por qué la mención de este texto es importante? La respuesta tiene que ver, primero, con la necesidad, fundamental para Ramírez, de dar cuenta de lo visto y lo vivido, es decir, de ofrecer el testimonio particular que habrá de oponerse a otras versiones (legitimadas o no) en aras de apuntalar su "verdad"; ${ }^{19}$ después, porque la alusión a esta crónica trae a cuestas, de manera implícita, la mixtura de discursos (ficcionales y documentales) que caracteriza, según algunas vertientes hermenéuticas, a la narrativa latinoamericana desde su gestación. ${ }^{20}$

Para Sergio Ramírez, en suma, la ficción es un discurso integral, que dicta "cómo ver a América, cómo interpretarla, cómo creerla, querer hacerla, querer transformarla" (Mentiras 116; cursivas mías). Al

imaginación creativa literaria para la reconstrucción de la Historia en contra del olvido" (136).

${ }^{19}$ El propio Ramírez recuerda que el texto de Bernal Díaz es una respuesta frente a la mendacidad que, según el cronista, caracteriza a la Historia de las Indias y conquista de México de Francisco López de Gómara.

${ }^{20}$ Tal es la línea argumentativa de Beatriz Pastor y Mercedes Serna, entre otros tantos críticos. De acuerdo con la tesis de Pastor, la llegada de Cristóbal Colón a tierras americanas supuso una nueva y particular forma de representar la realidad: "En sus diarios y cartas, el Almirante afirma describir cuando verifica, pretende desvelar cuando encubre, y describir cuando inventa. Dentro de unas coordenadas que determinan la función ficcionalizadora del discurso centrada en la necesidad personal y social que tiene el narrador de identificar América con sus modelos previos, por una parte, y de caracterizarla en función de las necesidades y expectativas del mercado europeo, por otra, Cristóbal Colón utiliza unas técnicas de descripción y caracterización cuyo resultado es la sustitución de la realidad americana por una ficción que expresa los sueños de realización personal y económica del Almirante" (34). Es precisamente este proceso de sustitución, "que oscilaba entre la invención, la deformación y el encubrimiento" (2), el que instaura una tradición narrativa donde se imbrican historia y ficción, realidad e imaginación, y cuyo eco pervivirá hasta nuestros días en gran parte de la novelística latinoamericana contemporánea, como desde otra veta hermenéutica plantea el mismo Ramírez. 
denunciar las lagunas o falsificaciones impuestas por la historiografía oficial (la vinculada al Estado), la literatura asume una labor crítica y revolucionaria: muestra los conflictos sociales — "dictaduras, intervenciones militares, revoluciones . . . lucha por la tierra, movimientos guerrilleros, miles de desaparecidos, campos de concentración, cementerios clandestinos, escuadrones de la muerte, masacres de indígenas, secuestros de recién nacidos" (El viejo arte 69) - ${ }^{21} \mathrm{y}$ proyecta, como envés, la sociedad deseable:

Mientras permanezca abierta la dicotomía entre sociedad real y sociedad ideal, el escritor estará siempre regresando a la Historia pública en busca no sólo de un escenario, sino de un motivo esencial, y tratará de representar el abismo que se abre entre esos dos mundos. Y su pretensión de actuar como filósofo de la historia, como vidente, como profeta, lo llevará a una búsqueda perpetua por reproducir la totalidad del universo social. (113; cursivas mías)

El autor de ficciones literarias es, en consideración de Ramírez, un individuo capaz de comprender mejor que otros el devenir del tiempo y, por tanto, facultado tanto para llevar a sus textos la complejidad del entramado social, como para vaticinar lo que habrá de ocurrir, siempre "ascendiendo, levitando por encima de la sustancia de la realidad” (Mentiras 43). A propósito, él mismo señala:

El intelectual, el instruido, el leído, el sabido, frente a un pueblo pobre, oprimido, es el que sabe más. El intelectual es el sajurín. . . el zahorí, el mago, el adivino, el que lo sabe todo,

${ }^{21}$ Además de estos temas, páginas más adelante Ramírez sugiere otros que, a su parecer, cobran preeminencia en los albores del siglo xxi: el narcotráfico, la corrupción, el derrumbe de la clase media, la contaminación, la pobreza extrema, la globalización y la migración. En sus novelas más recientes, Sombras nada más (2002), Mil y una muertes (2004), El cielo llora por mí (2008) La fugitiva (2011) y Ya nadie llora por mí (2017), las injusticias, la corrupción, el narcotráfico y la migración tienen un papel primordial. 
el de Las mil y una noches, el de las maravillas. Y en Nicaragua el escritor es como un zahorí, y el pueblo dice que el que sabe más está obligado a saberlo todo, no sólo porque escribe bonito sino porque si escribe bonito es porque está más instruido. ... Hay como una especie de delegación en el escritor, y por eso entiendo que los intelectuales, los escritores, a quienes he representado en la revolución, de alguna manera, tienen esa responsabilidad. (Oficios compartidos 26)

Llama la atención que el nicaragüense afirme que su poder, en tanto intelectual (ese "saberlo todo"), sea una atribución que la colectividad le confiere ("el pueblo dice") y no una cualidad que él mismo se imputa. Escribir trae a cuestas una responsabilidad social, una obligación en apariencia delegada por los otros: demostrar, a través del texto, que sabe más. ¿Y qué implica saber más? Fungir como "mago", "adivino" o "profeta", es decir, develar aquello que a los otros les está negado: mostrar las contradicciones sociales, evidenciar las argucias de los detentores del poder, alzar la voz frente a las injusticias y los agravios perpetrados en contra de aquellos a los que el escritor re/presenta: el pueblo "pobre” y "oprimido". Ramírez no pasa por alto que ejercer la literatura — sobre todo en América Latina - es una forma de excepcionalidad, pues no todos los ciudadanos tienen acceso a la escritura (ni mucho menos pueden vivir de lo que escriben); de ahí que al novelista le corresponda hablar por los demás y darles voz. ${ }^{22}$

De nuevo, entre las estrategias retóricas asumidas por el autor en sus dos ensayos sobresale la reiteración de un tópico recurrente: la del escritor como intermediario y vocero de las minorías. Las denominaciones a las que recurre ("profeta", "adivino", "vidente", "sabido" y demás) dan cuenta de la jerarquía que Ramírez le

22 Este deseo de hablar por los demás es patente en el testimonio La marca del Zorro, en el que Ramírez funge como interlocutor y organizador del relato del comandante Francisco Rivera Quintero, alias el "Zorro", guerrillero sandinista y uno de los protagonistas de la derrota de la Guardia Nacional somocista en 1979. 
atribuye al literato, además del cariz — rayano en lo sagrado— con que lo define. ${ }^{23} \mathrm{Nada}$ dice, en cambio, de los intereses particulares (sean personales o sectarios) que suelen agazaparse detrás de esta auto-asumida representación de los otros, ni mucho menos sobre la forma específica en que tales intereses permean el texto literario.

Así como el autor de ficciones es un agente social privilegiado, capaz de "traducir" artísticamente la complejidad del entramado social e incluso está dotado para, según Ramírez, transformar la realidad (aunque se olvida de decirnos cómo, específicamente, lo hará), también la literatura es el vórtice en torno al cual se articulan todos los otros discursos; el único lugar de enunciación apto para "registrar [dentro de sí] todas las ramas del conocimiento" (El viejo arte 115), a la manera de "una metáfora epistemológica de la realidad” (Rivera 131). Apunta Ramírez:

Como novelistas hemos querido siempre tocar todos los registros posibles, como ya se probó desde comienzos del siglo XX: no sólo los episodios de la Historia pública, sino también la geografía, la sociología, la antropología, la demografía, la etnología, la zoología, la botánica, la geología, la arqueología. (El viejo arte 114) ${ }^{24}$

${ }^{23} \mathrm{El}$ rol de mediador entre el pueblo y los detentores del poder político que Ramírez delega en el escritor de ficciones remite a la separación entre poder y saber que, a decir de Michel Foucault, es patente en Occidente desde la aparición de Edipo rey de Sófocles. De acuerdo con el filósofo francés, "cuando el poder es tachado de ignorancia, inconsciencia, olvido, oscuridad, por un lado quedarán el adivino y el filósofo en comunicación con la verdad, con las verdades eternas de los dioses o del espíritu, y por otro estará el pueblo que, aun cuando es absolutamente desposeído del poder, guarda en sí el recuerdo o puede dar testimonio de la verdad. Así, para ir más allá de un poder que se encegueció como Edipo, están los pastores que recuerdan y los adivinos que dicen la verdad" (60-61). Las denominaciones de "mago", "profeta" o "vidente" con que Ramírez describe al narrador de ficción cobran, a partir de la cita anterior, cabal sentido: el escritor fungirá como "adivino" y "filósofo" (rol que en la tragedia griega ocupa Tiresias): individuo calificado para acceder a la verdad que está negada a quienes poseen el poder político.

${ }^{24}$ Esta noción extensiva de la novelística latinoamericana tiene su correlato 
Por si fuera poco, además de asimilar todos los otros posibles géneros discursivos, la narrativa latinoamericana —en la que destacan, según el nicaragüense, escritores como Carlos Fuentes, Julio Cortázar, Alejo Carpentier, Gabriel García Márquez, Tomás Eloy Martínez, entre otros - debe incidir en la realidad extratextual y ser, ante todo, una "máquina de acción” (Ramos 40), es decir, una expresión que no desatiende los problemas sociales sino que se nutre de ellos. Aún resta saber cómo es que esta serie de reflexiones sobre el arte de escribir permite advertir el actual posicionamiento del propio Sergio Ramírez respecto a los dos ámbitos, el político y el literario, a los que ha consagrado su vida y frente a los cuales ha experimentado no pocos cambios.

\section{La literatura en la política y la política en la literatura}

Si hasta ahora he remarcado que la obra de Ramírez se distingue por un alto grado de compromiso social, vale la pena prestar atención a los vaivenes que, en la trayectoria del autor, sostiene la relación entre literatura y política, pues en ellos es dable advertir el correlato de las afirmaciones que construye tanto en Mentiras verdaderas como en El viejo arte de mentir. Desde sus inicios, Ramírez se caracterizó, tal como afirma Ángel Rama, por ser un "contestatario", por confrontar al poder hegemónico y autoritario de su país: muestra

en lo enunciado por Roberto González Echevarría: "Mi hipótesis es que, al no tener forma propia, la novela generalmente asume la de un documento dado, al que se le ha otorgado la capacidad de vehicular la 'verdad' - es decir, el poder-, en momentos determinados de la historia. La novela, o lo que se ha llamado novela en diversas épocas, imita tales documentos para así poner de manifiesto el convencionalismo de éstos, su sujeción" (38). Estos otros documentos a los que alude González son: la relación (informe, deposición, confesión, testimonio, carta, declaración) en la picaresca y en las primeras ficciones de y sobre América; las ciencias naturales y las ciencias sociales (manifestadas en el lenguaje de los viajeros que recorrieron el continente) durante el siglo xIx; y la antropología y la etnografía (por su interés en los mitos fundadores y en la indagación de la identidad cultural) en la novela moderna. 
de ello son los cuentos incluidos en De tropeles y tropelías (1971) y su novela $\dot{i}$ Te dio miedo la sangre? (1977), en los que denuncia y a la vez ridiculiza a la dinastía de los Somoza.

Sin embargo, durante los años más intensos de su actividad gubernamental en Nicaragua, luego del triunfo de la revolución popular sandinista —me refiero, sobre todo, al período comprendido entre 1984 y 1994-, Ramírez abandonó casi por completo la escritura de ficción (publicó Castigo divino en 1988 y el libro de relatos Clave de sol en 1992). Fue tal la implicación del nicaragüense en el nuevo proyecto político, que afirmó: "yo me digo, incluso, que podría ver a Sergio Ramírez sin ser escritor, pero que nunca podría yo imaginarme sin la revolución, porque creo que, sin la revolución, mi vida no tendría sentido" (Oficios compartidos 21). Esta noción, en la que el oficio de escritor está supeditado al de político, se modificó considerablemente a partir de las desavenencias que, más tarde, tuvo con Daniel Ortega — líder del FSLN y actual presidente de Nicaragua - y que culminaron con su total distanciamiento del aparato estatal de su país. ${ }^{25}$ Desde entonces, nuestro autor se convirtió en un agudo crítico de la realidad pos-revolucionaria nicaragüense y encabeza la disidencia sandinista: su posición es la de un intelectual que se erige como una especie de conciencia crítica del orden político imperante. ${ }^{26}$

${ }^{25}$ Las causas de dicha ruptura han sido expuestas por Ramírez en su libro testimonial Adiós muchachos. Una memoria de la revolución sandinista. Baste con consignar aquí que, luego de su enfrentamiento con Daniel Ortega, en 1995, Ramírez fundó el Movimiento Renovador Sandinista (MRS), con la finalidad de regresar a los orígenes ideológicos del sandinismo. A la cabeza de este movimiento y respaldado por varios dirigentes y simpatizantes de la revolución (Ernesto Cardenal, entre ellos), el autor de ¿Te dio miedo la sangre? se inscribió como candidato a la presidencia en las elecciones de 1996. De acuerdo con las declaraciones hechas por él mismo, la apabullante derrota (el MRS obtuvo menos del $2 \%$ de los votos), las deudas que contrajo para pagar su campaña electoral y la insistencia de su familia fueron las razones que lo llevaron a renunciar a su quehacer político.

${ }^{26}$ El concepto de intelectual debe entenderse de la siguiente manera: "no porque fueran los primeros en trabajar con «ideas», sino porque ciertas prácticas 
En pocos años, Sergio Ramírez pasó de escritor rebelde a político revolucionario, y más tarde, a desencantado detractor del FSLN y, sobre todo, del gobierno "caudillista" de Ortega. A esta última etapa, es vital no olvidarlo, pertenecen Mentiras verdaderas y El viejo arte de mentir, a pesar de la siguiente advertencia del autor:

Siempre he tenido mucho miedo a que la acción política influyera en la recreación literaria, en convertir la ficción en participación propia. Cuando estábamos en el poder, o en la lucha, escribir sobre mi compromiso me causaba terror porque pensaba que podía contaminarse mi literatura con las posiciones políticas o ideológicas. Inevitablemente, uno se vuelve agente de relaciones públicas de la causa que defiende y la literatura no es invulnerable a eso. Estoy convencido que las obras de propaganda son siempre fallidas, excepto Casablanca, y por eso, cuando dejé el poder y salí como disidente, también me dio miedo porque me causaba cierta repulsión la literatura disidente, la que se utiliza para hacer denuncias o para saldar cuentas con los viejos compañeros. (Plaza 77)

Es, sin lugar a dudas, relevante que, pese a la insistencia en el ineludible entrecruzamiento entre literatura, historia y política, Ramírez manifieste temor de que su obra pudiese "contaminarse" debido a su filiación y militancia, como si hubiese la posibilidad de una escritura "en pureza", desprovista de propaganda alguna, neutral en la medida en que se mantiene a distancia (es decir, al margen) de los grupos y sectores en disputa. Pareciera como si la declarada pertenencia a una facción (se trate del Estado o de la disidencia) que se enfrenta por el poder político "corrompiera" cualquier expresión artística y la "desviara" de su entereza ideológica.

De lo anterior debe deducirse que ese miedo fue el que contuvo al autor de publicar ficción mientras fungió como vicepresidente

intelectuales, sobre todo ligadas a la literatura, comenzaban a constituirse fuera de la política y frecuentemente opuestas al Estado” (Ramos 71). 
y también el que lo mantuvo a reserva de saldar cuentas con sus antiguos co-partidarios. ${ }^{27}$ Sin embargo, y pese a su negativa a hacer proselitismo de cualquier tipo, lo cierto es que Ramírez se ha servido de su notoriedad como escritor para intervenir, cada que le es posible, sobre política: es "consultado con frecuencia acerca de sus opiniones políticas aunque declare su renuncia a ese campo" (Seoane 98) y está siempre "muy predispuesto también a hablar de la revolución como de su propia trayectoria" (98-99). ${ }^{28}$ Desde el ámbito literario, tampoco son escasas, intrascendentes o "incontaminadas" sus expresiones: en su más reciente novela, $\mathrm{Ya}$ nadie llora por mí, por ejemplo, recurre a las convenciones del género negro para exponer la corrupción, la violencia y la falsedad de la Nicaragua de Daniel Ortega.

Otro tanto puede decirse a propósito de los ensayos aquí tratados: ellos son parte de los demás géneros a los que el autor recurre para manifestar su posición no solo respecto al campo literario, sino, de igual modo, al político. Dicho esto, no extraña que Ramírez postule la ficción narrativa como la palestra idónea en que se dirimen los problemas sociales: en ella encuentra el lugar más indicado (puesto que la literatura está, no debemos olvidarlo, sobre cualquier otro discurso) para hablar de política, de historia, de los avatares de la sociedad toda. De lo anterior se desprende que ningún político (Ortega incluido) está capacitado como el novelista (Ramírez, en este caso) para hablar de política, así como ningún

27 "La primera novela que me atreví a escribir sobre los hechos de la revolución fue Sombras nada más, y la hice cuando me sentía lo bastante lejos de aquella experiencia y sobre un episodio marginal dentro del tablero político, en el momento en el que el Frente Sandinista va a tomar el poder en 1979. No pertenece a la gran épica, sino a una pequeña épica oscura. Y ahí he dejado mi experiencia política dentro de la literatura. No he ido más allá” (ctd. en Plaza 78).

${ }^{28}$ Una prueba de estas constantes intervenciones políticas del nicaragüense es la entrevista que concedió, el 17 de noviembre de 2014, a la revista digital Viceversa: en ella se pronuncia en contra de presidentes latinoamericanos como Hugo Chávez, Rafael Correa y Evo Morales. Cfr. Landaeta, José Luis. "Sergio Ramírez: 'el cuadillo es un engendro de la sociedad rural"'. 
historiador, antropólogo o humanista, puede encarar, como el literato, los sucesos de la vida pública. ${ }^{29}$

En vista de que, a diferencia de otros puntos de vista sobre la realidad, "una novela ... es irrefutable, y lo que nos cuenta vendrá a ser, al fin y al cabo, lo creíble" (El viejo arte 123), la narrativa - y, en particular, la literatura de "imaginación" que el nicaragüense propone - se salva así misma por "mentirosa" de cualquier posible objeción dirigida en su contra. La propuesta del autor se funda en generar un lugar de enunciación que lo valida como "reproductor fiel de la realidad" y "profeta", a la vez que rechaza, a priori, toda discrepancia para con su discurso.

A lo largo de Mentiras verdaderas y El viejo arte de mentir, Ramírez entrecruza constantemente el ámbito literario y el político con el afán de apuntalar sus (polémicas, generalizadas, contradictorias) nociones sobre la narrativa de ficción y su función social. Las paradojas, generalizaciones y debilidades de su argumentación —el énfasis en la subjetividad que caracteriza a la ficción y, al mismo tiempo, su facultad de reproducir la "totalidad" del universo social; la disimilitud entre los textos que homologa como provistos de imaginación; la reiterada superioridad del escritor y su facultad para expresar, mediante la palabra escrita, al pueblo, pese a la innegable brecha que separa a aquel de este; su insistencia en la función social y política de la literatura (capaz de colocarla por encima de cualquier otro tipo de discurso) al mismo tiempo que vilipendia el posicionamiento político de los autores en las obras- deben

\footnotetext{
${ }^{29}$ Así lo refrenda el siguiente párrafo, en el que Ramírez pondera los atributos denunciatorios de la literatura: "Cerrar los ojos, apagar la luz, bajar la cortina es traicionar el oficio. Todo irá a desembocar tarde o temprano en el relato, todo entrará sin remedio en las aguas de la novela. Y lo que calla o mal escribe la historia, lo dirá la imaginación, dueña y señora de la libertad . . pues no bay nada que pueda y deba ser más libre que la escritura, en mengua de sí misma cuando paga tributos al poder que, cuando no es democrático, sólo quiere fidelidades incondicionales" ("Discurso íntegro"). Nótese, por lo demás, que la aseveración es concluyente: la ficción narrativa tiene una potestad mayúscula y desatender la vida social implica una deslealtad al oficio.
} 
ser vistas como parte de un complejo andamiaje retórico mediante el que Ramírez desea hacer valederas sus ideas (sus "mentiras", podría decirse) sobre el arte de narrar. La "verdadera" literatura (realista, imaginativa y enfrentada al Estado) que Ramírez blande está hecha del mismo material utilizado en la confección de sus ensayos: mentiras verosímiles. La mentira - concepto matriz en ambos ensayos - funge como un recurso bifronte: vela y desvela, muestra y oculta al mismo tiempo. La eficacia de Mentiras verdaderas y El viejo arte de mentir consiste en proponer un modo específico de narrar que valida, implícitamente, la escritura de su autor a la vez que posibilita su incursión e idoneidad para incidir en el terreno político. Forma y contenido se amalgaman admirablemente en estos ensayos, muestra palmaria de que en la literatura convergen lo referido y lo inventado para articular un discurso que desea autentificar la ficción como trinchera insuperable para arremeter contra cualquier verdad sospechosa.

\section{Bibliografía}

Beristáin, Helena. "Verosimilitud". Diccionario de retórica y poética. 9a ed., Porrúa, 2008.

Carpentier, Alejo. Prólogo. El reino de este mundo, Obras completas, vol. 2, Siglo XXI, 1985, pp. 13-18.

Chiampi, Irlemar. El realismo maravilloso. Forma e ideología en la novela hispanoamericana. Monte Ávila, 1983.

Dorfman, Ariel y Armand Mattelart. Para leer al Pato Donald. Comunicación de masa y colonialismo. Siglo XXI, 1978, pp. 3-8.

Eco, Umberto. El superhombre de masas. Traducción de Teófilo de Lozoya, Debolsillo, 2005.

Foucault, Michel. La verdad y las formas jurídicas. Traducción de Enrique Lynch, Gedisa, 2012.

Freud, Sigmund. "El creador literario y el fantaseo". Obras completas, Traducción directa del alemán de José L. Etcheverry, ordenamiento, comentarios y notas de James Strachey con la colaboración de Anna Freud, vol. IX, Amorrortu, 1999, pp. 123-135. 
González Echevarría, Roberto. Mito y archivo. Una teoría de la narrativa latinoamericana. Traducción de Virginia Aguirre, Fondo de Cultura Económica, 2011.

Horkheimer Max y Theodor W. Adorno. "La industria cultural. Ilustración como engaño de masas". Dialéctica de la Ilustración. Fragmentos filosóficos, Introducción y selección de Juan José Sánchez, Trotta, 1998, pp. 165-212.

Jakobson, Roman. "Sobre el realismo artístico". Teoría de la literatura de los formalistas rusos, compilación de Tzvetan Todorov, Siglo XXI, 2007, pp. 71-79.

Landaeta, José Luis. "Sergio Ramírez: 'el cuadillo es un engendro de la sociedad rural"'. Viceversa, 17 de noviembre de 2014, www. viceversa-mag.com/sergio-ramirez-entrevista/

Mariátegui, José Carlos. "La realidad y la ficción". Textos básicos, selección, prólogo y notas de Aníbal Quijano, Fondo de Cultura Económica, 1991.

Pastor, Beatriz. Discurso narrativo de la Conquista de América: mitificación y emergencia. Casa de las Américas, 1983.

Plaza, Caridad. "Diálogo de la lengua. Entrevista a Ricardo Piglia y Sergio Ramírez". Quórum, 21, Casa de América, 2010, pp. 70-83.

Rama, Ángel. Novísimos narradores hispanoamericanos en Marcha: 1964/1980. Marcha editores, 1981.

Ramírez, Sergio. "Balcanes y volcanes (la pluma debajo del sombrero)". Balcanesy volcanesy otros ensayosy trabajos, 1973, www.cervantesvirtual. com/obra-visor/balcanes-y-volcanes-la-pluma-debajo-del-sombrero/html/9de64678-7ff1-4cd2-b0cf-8324ccb6b5a0_6.html\#I_0_

- - -. "Discurso íntegro de Sergio Ramírez, Premio Cervantes 2017”. El País, 23 de abril de 2018, elpais.com/cultura/2018/04/23/ actualidad/1524479702_299237.html

- - - . El viejo arte de mentir. Instituto de Estudios Superiores de Monterrey/Fondo de Cultura Económica, 2004.

- - . Mentiras verdaderas. Alfaguara, 2001.

- - -. Oficios compartidos. Siglo XXI, 1994.

Ramos, Julio. Desencuentros de la modernidad en América Latina. Literatura y politica en el siglo XIX. Fondo de Cultura Económica, 1989. 
Rivera, Melba Julia. "Epílogo. Los escritores: ángeles guardianes de la memoria". El viejo arte de mentir, pp. 129-137.

Schmucler, Héctor. "Donald y la Política". Para leer al Pato Donald. Comunicación de masa y colonialismo, Siglo XXI, 1978, pp. 3-8.

Skirius, John. "Este centauro de los géneros". Traducción de David Huerta, El ensayo hispanoamericano del siglo XX. Fondo de Cultura Económica, 2006, pp. 9-30.

Vargas Llosa, Mario. La verdad de las mentiras (ensayos sobre literatura). Seix Barral, 1991. 